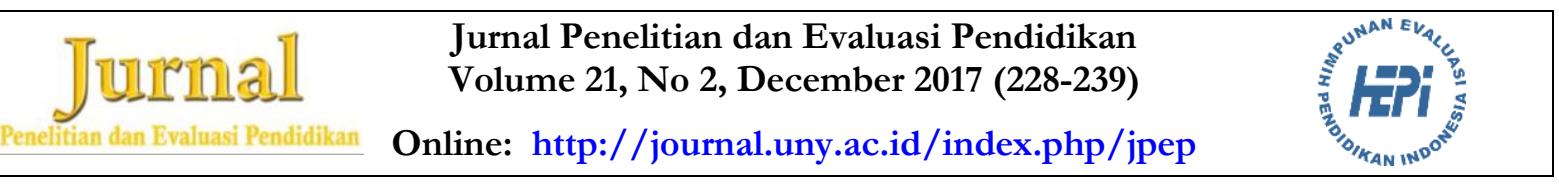

\title{
EVALUASI PROSES BIMBINGAN SKRIPSI MAHASISWA UNIVERSITAS NEGERI YOGYAKARTA BERDASAR PERSPEKTIF PEMBELAJARAN ORANG DEWASA
}

\author{
Sugito ${ }^{1 *}$, Sunaryo Soenarto ${ }^{1}$, Entoh Tohani ${ }^{1}$ \\ ${ }^{1}$ Universitas Negeri Yogyakarta \\ 1Jl. Colombo No. 1, Depok, Sleman 55281, Yogyakarta, Indonesia \\ * Corresponding Author. Email: sugito@uny.ac.id
}

\begin{abstract}
Abstrak
Dalam menghadapi tantangan dan permasalahan abad kedua puluh satu ini, pendidikan tinggi memiliki peran yang sangat strategis. Mata kuliah Skripsi dapat berperan untuk mengembangkan kemampuan guna menghadapi tantangan dan masalah yang dihadapi. Penelitian ini bertujuan untuk mengevaluasi proses pembimbingan skripsi dari perspektif teori pembelajaran orang dewasa, hambatan dan upaya yang dilakukan mahasiswa dan dosen dalam proses penulisan skripsi mahasiswa Universitas Negeri Yogyakarta (UNY). Penelitian ini dilakukan dengan menggunakan pendekatan kuantitatif. Sebagai sampel adalah mahasiswa yang sudah menyelesaikan penulisan skripsi, dan dosen pembimbing. Keduanya diambil secara purposif. Jumlah responden adalah 190 orang mahasiswa dan 53 orang dosen. Data dikumpulkan dengan menggunakan angket. Data yang diperoleh melalui angket dianalisis secara deskriptif kuantitatif dengan teknik persentase. Hasil penelitian menunjukkan: (1) proses pembimbingan cenderung sudah menggunakan prinsip pembelajaran orang dewasa, yang lebih menekankan pada proses belajar mandiri; (2) hambatan yang dihadapi meliputi substansi dan metode penelitian, kemampuan bahasa asing, psikologis, dan kelengkapan sumber referensi; dan (3) upaya yang dilakukan untuk mengatasi hambatan meliputi peningkatan motivasi diri, berusaha sendiri dan pemberian kesempataan dosen pada mahasiswa untuk menyampaikan permasalahan yang dihadapi.
\end{abstract}

Kata kunci: bimbingan skeripsi, pembelajaran orang dewasa

\section{EVALUATION OF UNDERGRADUATE THESIS MENTORING PROCESS IN UNIVERSITAS NEGERI YOGYAKARTA BASED ON ADULT LEARNING PERSPECTIVE}

\begin{abstract}
In facing the twenty-first century's challenges and problems, higher education plays a very strategic role. Undergraduate thesis can contribute in developing the ability to address the challenges and problems. This study aims at evaluating the process of mentoring through the lens of adult learning theory by looking at the students' and lecturers' obstacles and efforts in the process of thesis writing among college students. This research was conducted using a quantitative approach with a purposively selected sample of 190 students who have completed their thesis writing, and 53 supervisors. The data were collected by questionnaire and analyzed descriptively in percentages. The results show that: (1) the process of mentoring tends to have used the principle of adult learning with more emphasis on self-directed learning; (2) the encountered obstacles include research substance and methods, foreign language abilities, psychological factors, and reference sources; and (3) some activities done to overcome the obstacles include improving self-motivation, self-effort, and providing opportunities for the students to consult their problems to the lecturer.
\end{abstract}

Keywords: undergraduate thesis, mentoring, adult learning

Permalink/DOI: http://dx.doi.org/10.21831/pep.v21i2.17150

Jurnal Penelitian dan Evaluasi Pendidikan

ISSN 1410-4725 (print) ISSN 2338-6061 (online) 


\section{Pendahuluan}

Pada abad 21 ini terdapat berbagai tantangan dan permasalahan yang sangat kompleks (Brew, 2013, pp. 603-618). Peningkatan industri pengetahuan, inovasi dalam teknologi informasi dan komunikasi, orientasi pada ekonomi pasar dan perkembangan sistem tata kelola di tingkat regional dan internasional telah mengakselerasi arus manusia, ide, budaya, teknologi, barang dan jasa (Yamada \& Yamada, 2016). Para ahli menggambarkan abad ini sebagai cognitive capitalism; post-industrial society, neoliberal society, the information society, entrepreneurial society, postcapitalist society, risk society, and boring society (Kovacevic \& Pavlovic, 2016, p. 97).

Dalam menghadapi kondisi ini, dibutuhkan kemampuan dan keterampilan yang berbeda dengan masa sebelumnya. Dari hasil kajian terhadap berbagai hasil studi, Flynn (2014, pp. 361-384) mengidentifikasi ada enam kemampuan yang diperlukan dalam memasuki kehidupan abad ke 21 ini, yaitu: kemampuan memproses informasi, bekerja sama dalam suatu tim, kemampuan berkomunikasi, beradaptasi/fleksibel, ICT, pemecahan masalah/berpikir kritis, dan inovasi. Dalam studi lain, Husin et al. (2016) menemukan ada empat kemampuan, yaitu: digital age literacy, Inventive thinking, Effective communication and High productivity. Dalam konteks Malaysia ia menambahkan satu kemampuan lagi, yaitu: spiritual. Sementara itu, Magolda (2007, p. 16) menyatakan bahwa twenty-first-century learning outcomes require self-authorship: the internal capacity to define one's belief system, identity, and relationships.

Dalam kurikulum pendidikan tinggi, riset memiliki peran yang sangat strategis dalam mengembangkan kemampuan untuk menghadapi abad 21 tersebut. Beberapa penelitian menunjukkan bahwa keterlibatan mahasiswa dalam melaksanakan riset dapat mengembangkan kemampuan akademik dan sosial. Penelitan mahasiswa memiliki keuntungan, seperti kemampuan analitik, berpikir sintetik, meningkatkan kepercayaan akan kemampuan membuat presentasi dan berbicara di forum (Webber, Laird, \& BrckaLorenz, 2013).
Dari hasil kajian terhadap program penelitian mahasiswa S1 di beberpa perguruan tinggi diketahui bahwa program ini dapat mengembangkan kemampuan akademik. Penelitian Odera, Lamm, Odera, Duryea, \& Davis (2015) menemukan bahwa mahasiswa yang terlibat dalam proyek penelitian memperoleh keterampilan praktis untuk melakukan penelitian dan sumber-sumber yang penting di bidang studinya, keterampilan berpikir kritis, berpikir logis, dan kemapuan mensintesakan informasi. Di samping itu, 64\% dari responden melanjutkan ke program jenjang $\mathrm{S} 2,69 \%$ bekerja di bidang yang relevan dengan bidang studinya.

Dalam bidang fisika dan kimia, dalam penelitian longitudinal Harsh, Maltese, \& Tai (2011) menemukan bahwa proyek penelitian mahasiswa dapat mengembangkan kesiapan mahasiswa dalam memasuki bidang karier pekerjaannya. Pengenalan dalam bidang kerja secara otentik dipandang memberikan kontribusi nilai yang sangat besar. Di samping itu, dalam bidang sosial, Ishiyama (2002, p. 385) menemukan bahwa proyek penelitian mahasiswa dapat meningkatkan kemampuan berpikir, integrasi konsep, belajar mandiri dan menemukan informasi yang dibutuhkan untuk menyelesaikan tugas. Secara rinci, Hunter, Laursen, \& Seymour (2007, p. 46) memberikan ilustrasi tentang kemampuan yang diperoleh dari proses penelitian sebagai berikut: (1) thinking and working like a scientist. Aplikasi pengetahuan dan ketrampilan: memahami penelitian ilmiah melalui pengalaman langsung (berpikir kritis/pemecahan masalah, menganalisis dan menginterpretasikan hasil), memahami hakekat pengetahuan ilmiah (open ended, dan terkonstruksi secara berkelanjutan), memahami strategi pemecahan masalah, memahami pengetahuan/pemahaman sains dan kerja penelitian (teori, konsep dan hubungannya dengan sains); (2) becoming a scientist. Sikap dan perilaku sebagai ilmuwan (memiliki kegiatan penelitian, tanggung jawab, keterlibatan intelektual, inisiatif, kreativitas, kemandirian dalam pembuatan keputusan), memhamai hakikat kerja penelitian ilmiah, dan praktik profesional; (3) personal- 
professional. Kemampuan melakukan penelitian, berkontribusi terhadap sains, presentasi dan mempertahankan penelitian, merasa sebagai ilmuwan, membangun hubungan kolegialitas, bekerja sama dengan teman sebaya, dosen dan pembimbing. (4) clarification, confirmation, and refinement of career/education paths. Minat pada bidang kerja, klarifikasi pendidikan lanjut, pengetahuan tentang karier dan pendidikan, pengenalan bidang studi baru. (5) Enhanced career/graduate school preparation. Pengalaman kerja riil, persiapan studi lanjut/pekerjaan, kesempatan kolaborasi/kerja sama dengan dosen, teman sebaya, para ilmuwan di bidang yang lainnya; (6) Skills. Keterampilan berkomunikasi, presentasi, menulis laporan, bekerja dalam organisasi, memahamai bahan bacaan, bekerja secara kolaboratif. (7) Working independently. Keterampilan yang tidak berhubungan dengan praktik profesional.

Atas dasar pertimbangan manfaat yang diperoleh dari kegiatan penelitian mahasiswa, beberapa perguruan tinggi di Amerika menyelenggarakan kegiatan ko-kurikuler program penelitian bagi mahasiswa (Jenkins \& Healey, 2010, p. 36). Sementara itu, perguruan tinggi di Australia sekarang mulai memikirkan perlunya memasukan riset dalam kurikulum program pendidikan sarjana. Sebagaimana dinyataakan oleh Dobozy (2011, p. 41) Australian universities seem to join what has been portrayed as an "international movement" in the reconceptualisation of undergraduate education to include research components into the typical undergraduate education curriculum.

Sejalan dengan perkembangan tersebut, pemerintah Indonesia telah mengeluarkan kebijakan tentang perlunya menempatkan skripsi atau tugas akhir dalam kurikulum pendidikan tinggi. Sebagaimana dinyatakan dalam Peraturan Menteri Pendidikan dan Kebudayaan Republik Indonesia Nomor 49 Tahun 2014 tentang Standar Nasional Pendidikan Tinggi (Menteri Pendidikan dan Kebudayaan Republik Indonesia, 2014) bahwa:

"mampu mengkaji implikasi pengembangan atau implementasi ilmu pengetahuan teknologi yang memperbatikan dan menerapkan nilai bumaniora sesuai dengan keabliannya berdasarkan kaidah, tata cara dan etika ilmiah dalam rangka menghasilkan solusi, gagasan, desain atau kritik seni, menyusun deskripsi saintifik hasil kajiannya dalam bentuk. skripsi atau laporan tugas akbir, dan mengunggahnya dalam laman perguruan tinggi; "

Mahasiswa tingkat sarjana berada pada usia dewasa awal. Pada masa ini individu memiliki karakteristik dan kebutuhan pembelajaran yang berbeda. Sebagaima dinyatakan oleh Knowles, Holton III, \& Swanson, 2005 (pp. 62-64) bahwa peserta didik orang dewasa memiliki karakteristik sebagai berikut: (1) kebutuhan untuk mengetahui. Kebutuhan untuk mengetahui alasan mengapa mereka perlu mempelajari sesuatu sebelum mereka melakukan proses belajar; (2) konsep diri. Peserta didik orang dewasa memiliki konsep diri, sebagai individu yang dapat bertanggung jawab terhadap keputusan dan kehidupannya. Mereka memiliki kebutuhan yang dalam untuk diperlakukan sebagai individu yang dapat mengarahkan dirinya sendiri; (3) pengalaman. Peserta didik orang dewasa sudah memiliki banyak dan beragam pengalaman, dan pengalaman ini menjadi sumber belajar yang sangat berharga; (4) kesiapan belajar. Kesiapan belajar peserta didik orang dewasa berkaitan dengan tugas perkembangan yang dimiliki. Mereka siap mempelajari sesuatu yang mereka butuhkan untuk mengetahui dan mengatasi situasi kehidupan nyata; (5) orientasi belajar. Orientasi belajar orang dewasa adalah kehidupan atau masalah. Orang dewasa termotivasi untuk belajar manakala mereka memandang bahwa pembelajaran tersebut akan membantu mereka mengatasi masalah yang mereka hadapi; (6) motivasi. Motivasi peserta didik orang dewasa bersumber dari dalam diri sendiri, bukan bersumber dari faktor eksternal.

Penelitian ini bertujuan untuk mengkaji proses pembimbingan penulisan skripsi dari perspektif pembelajaran orang dewasa. Bagaimana pandangan mahasiswa dan dosen tentang proses pembimbingan skripsi mahasiswa Universitas Negeri Yogyakarta (UNY)? Faktor-faktor apa saja yang menjadi 
hambatan dan upaya yang dilakukan mahasiswa dan dosen untuk mengatasi hambatan penulisan skripsi mahasiswa UNY? Hasil dari kajian ini diharapkan dapat memberikan informasi tentang kebutuhan proses pembimbingan skripsi mahasiswa.

\section{Metode Peneltian}

Populasi penelitian ini adalah mahasiswa yang menulis skripsi pada tahun akademik 2015/2016, dan dosen pembimbing skripsi UNY. Sampel diambil secara purposive. Sesuai dengan tujuan penelitian, ada beberapa faktor yang dijadikan pertimbangan dalam pengambilan sampel, yaitu: (a). sampel mahasiswa: asal fakultas, penyelesaian penulisan skripsi, jenis kelamin, lama waktu penyelesaiaan penulisan skripsi, b). Sampel dosen: asal fakultas, dan jabatan akademik dosen. Jumlah responden mahasiswa ada 190 orang, terdiri atas 27 orang dari Fakultas Ilmu Pendidikan (FIP), 56 orang dari Fakultas Bahasa dan Seni (FBS), 23 orang dari Fakultas Matematika dan Ilmu Pengetahuan Alam (FMIPA), 50 orang dari Fakultas Teknik (FT), dan sebanyak 34 orang dari Fakultas Ekonomi (FE). Dari jumlah tersebut sebanyak 111 orang perempuan dan 79 orang laki-laki. Jika diihat dari lama penyelesaian skripsi, sebanyak 33 orang mahasiswa menyelesaikan penyusunan skripsi dalam waktu kurang dari 6 bulan $(17,4 \%)$, sebanyak 113 orang menyelesaikan dalam waktu 6 sampai 12 bulan atau 59,5\%, 36 orang menyelesaikan dalam waktu lebih dari 12 bulan atau $18,9 \%$, dan sebanyak 8 orang atau $4,2 \%$ tidak memberikan keterangan. Sementara itu, responden dosen jumlah keseluruhan ada 53 orang, yang terdiri atas 11 orang dosen FIP, 26 orang dosen FMIPA, 4 orang dosen FIS, 2 orang dosen dari FE, 2 orang dosen FIK, dan 8 orang dosen FT. Dilihat dari jabatan dosen, 15 orang adalah lektor kepala, 23 orang adalah lektor, 6 orang asisten ahli, dan tidak memberikan jawaban sebanyak 9 orang.

Variabel penelitian ini adalah (1) manfaat penulisan skripsi, (2) proses pembimbingan skripsi, (3) hambatan yang dihadapi dalam pembimbingan penulisan skripsi, dan
(4) upaya untuk mengatasi hambatan. Manfaat adalah nilai tambah yang diperoleh mahasiswa dan dosen dalam proses penulisan skripsi. Proses pembimbingan adalah caracara pendampingan yang digunakan dalam membantu mahasiswa menulis skripsi. Hambatan adalah faktor-faktor yang menjadi kendala dalam proses penulisan dan pembimbingan skrispi baik yang dihadapi mahasiswa maupun dosen pembimbing. Upaya adalah usaha dan cara yang dilakukan dosen dan mahasiswa untuk mengatasi hambatan yang dihadapi.

Pengumpulan data dilakukan dengan menggunakan angket yang diadaptasi dan dikembangkan dari Deloach, PerrySizemore, \& Borg (2012) dan Mancha \& Yoder (2014). Aspek-aspek yang diungkap melalui angket meliputi: (1) proses pembimbingan yang terdiri atas metode dan pola bimbingan, sumber belajar, proses analisis data, bentuk usaha yang dilakukan mahasiswa, dan fasilitas pendukung, dan (2) hambatan yang dihadapi dalam penulisan skripsi mencakup hambatan dalam substansi materi, sarana pendukung, pengumpulan dan analisis data, emosional, dan (3) upaya yang dilakukan mahasiswa dan dosen dalam mengatasi masalah tersebut. Angket berupa pernyataan dan alternatif pilihan jawaban. Responden diminta menjawab setiap pernyataan dengan memilih alternatif jawaban secara berjenjang sesuai dengan tingkat intensitasnya.

Sesuai dengan tujuan penelitian dan jenis data yang diperoleh, maka data yang telah dikumpulkan dianalisis secara deskriptif kuantitatif dengan teknik persentase. Analisis persepsi dosen dan mahasiswa terhadap proses bimbingan dilakukan dengan memperhatikan modus jawaban responden dalam setiap aspek fokus kajian dan tingkatan intensitas dari jawaban.

\section{Hasil Penelitian}

Pandangan Mahasiswa dan Dosen terhadap Proses Bimbingan

Pandangan mahasiswa dan dosen mengenai proses pembimbingan skripsi meli- 
puti: proses pembimbingan, hambatan yang ada, dan upaya mengatasi hambatan baik oleh mahasiswa maupun dosen. Secara lebih rinci hasil penelitian dapat dideskripsikan berikut ini.

\section{Proses Pembimbingan}

Proses bimbingan yang diungkap meliputi pendalaman materi skripsi, bentuk pertemuan, metode, media, proses belajar, sumber belajar, dan sarana. Pertama, cara pendalaman materi. Dalam pendalam materi bimbingan ada enam aspek yang diuangkap, yaitu: menerima apa saja saran dosen, mempertimbangkan saran dosen, mengajukan pendapat/usul pada dosen, mendiskusikan dengan dosen, meminta penjelasan lebih lanjut, melakukan kajian secara mandiri.

Pandangan mahasiswa dan dosen terhadap cara pendalaman materi skripsi memiliki perbedaan dan kesamaan. Mayoritas dosen menempatkan tindakan pendalaman materi skripsi dalam bentuk mempertimbangkan masukan dosen pada intensitas keempat $(32,1 \%)$, menyampaikan pendapat kepada dosen pada intensitas ketiga $(35,8 \%)$, dan meminta penjelasan lebih lanjut kepada dosen ditempatkan pada intesitas kedua (34\%). Sebaliknya, mayoritas mahasiswa mempersepsikan ketiga tindakan tersebut dengan masing-masing intensitas ketiga $(26,8 \%)$, kedua $(25,3 \%)$ dan keempat $(25,3 \%)$. Namun demikian, terdapat kesamaan persepsi antara keduanya yaitu baik dosen $(23 \%)$ maupun mahasiswa (67\%) mempersepsikan tindakan mendiskusikan dengan dosen untuk pendalaman materi skripsi sebagai prioritas pertama, dan untuk tindakan menerima apa saja yang dikemukakan dosen dan kajian mandiri oleh mahasiswa pada masing-masing intensitas keenam. Dengan demikian dapat dikatakan bahwa cara memperdalam materi skripsi dilakukan dengan mendiskusikan bersama antara dosen dan mahasiswa, dan tidak menerima apa saja pendapat dosen, namun kurang melakukan kajian mandiri.

Kedua, metode bimbingan. Ada tiga pilihan metode bimbingan yang diajukan, yaitu: masukan secara tertulis, masukan le- wat media elektronik dan tatap muka langsung. Dosen $(75,5 \%)$ dan mahasiswa $(64,2 \%)$ menempatkan metode tatap muka sebagai intensitas pertama, sedangkan metode masukan tertulis dan elektronik mendapatkan intensitas kedua dan ketiga. Hal ini menunjukkan bahwa dalam proses bimbingan, metode yang banyak digunakan adalah metode tatap muka.

Ketiga, model bimbingan. Ada kesamaan pandangan antara dosen dan mahasiswa terhadap model bimbingan dalam penyusunan skripsi. Pada umumnya dosen $(83 \%)$ dan mahasiswa $(78,9 \%)$ menempatkan model bimbingan individu dipandang sebagai intensitas pertama, bimbingan individu dan kelompok dipandang memiliki intensitas kedua, dan intensitas ketiga untuk bimbingan kelompok. Dengan kata lain, model bimbingan yang dilakukan cenderung menekankan pada bimbingan individu.

Keempat, sumber belajar. Ada enam pilihan sumber belajar yang diungkap, yaitu: buku, jurnal internasional, jurnal nasional, prosiding, dan artikel di internet. Ada kesamaaan persepsi dosen dan mahasiswa mengenai penggunaan sumber belajar. Pada umumnya dosen (74\%) dan mahasiswa (74\%) menempatan buku pada intensitas pertama. Terhadap jurnal nasional keduanya pun mempersepsikan hal sama yaitu pada intensitas kedua. Terhadap prosiding pun, dosen dan mahasiswa memandang sama dimana keduanya memposisikan dengan intensitas keempat. Begitu pula hal yang sama terhadap penggunaan sumber belajar dalam wujud artikel internet, dimana diposisikan dengan intensitas kelima. Namun demikian, baik dosen maupun mahasiswa memiliki pandangan berbeda dalam hal penggunaan jurnal internasional, dimana dosen mempersepsikan penggunaan sumber belajar jurnal internasional pada intensitas ketiga sedangkan mahasiswa memposisikannya dengan intensitas kelima. Dengan demikian dapat dikatakan bahwa penggunaan jurnal internasional di kalangan mahasiswa belum menjadi prioritas penting dalam proses penyusunan skripsi. 
Kelima, proses analisis data. Ada empat pilihan cara analisis data yang diajukan, yaitu: dilakukan sendiri oleh mahasiswa, dibimbing dosen, bersama dengan teman, dan melalui biro jasa, Pada umumnya dosen $(38 \%)$ dan mahasiswa (62\%) menempatkan analisis data secara mandiri pada intensitas pertama. Hal yang sedikit berbeda terjadi pada proses analisi data yang dilakukan mahasiswa dengan cara dibimbing oleh dosen, dimana mayoritas dosen memposisikan sebagai intensitas pertama (47\%), sedangkan mahasiswa memandang sebagai intensitas kedua (41\%). Sedangkan pada penggunaan biro jasa baik dosen maupun mahasiswa menyatakan pendapat sama yaitu memposisikan pada intensitas keempat, dan intensitas ke tiga bagi analisis data dengan bantuan teman. Dari informasi ini, dapat disimpulkan bahwa analisis data lebih cenderung dilakukan secara mandiri oleh mahasiswa.

Keenam, bentuk usaha penulisan. Ada 5 jenis pilihan yang diajukan, yaitu: mencari sendiri sumber belajar, menunggu arahan dosen, mengikuti kata dosen, berdiskusi dengan dosen, berdiskusi dengan teman. Dosen dan mahasiswa memiliki kesamaan pandangan mengenai bentuk usaha yang dilakukan dalam proses bimbingan, dimana mayoritas dosen (43\%) dan mahasiswa (61\%) menempatkan mencari sumber belajar secara mandiri pada intesitas pertama. Sementara itu, usaha dalam bentuk menunggu arahan dipandang oleh kedua kelompok sebagai kegiatan yang menempati intensitas keempat atau terakhir. Mengikuti kata dosen, diungkapkan keduanya sebagai intensitas kelima, dan diskusi dengan teman sebagai intensitas ketiga. Terdapat perbedaan pada usaha diskusi dengan dosen, yang mana dosen menyatakan sebagai intensitas pertama sedangkan mahasiswa menyatakan sebagai intensitas kedua. Dengan data ini, dapat simpulkan bahwa dalam proses bimbingan, mahasiswa mencari sendiri sumber belajar yang digunakan dalam penulisan skripsi, dan diskusi dengan dosen.

Ketujuh, fasilitas penunjang. Fasilitas penunjang meliputi laboratorium, perpustakaan, ruang diskusi, komputer, layanan jurnal dan internet. Persepsi dosen dan mahasiswa menunjukkan kesamaan terhadap pemanfaatan fasilitas perpustkaan, dan laboratorium. Pada umumnya dosen (38\%) dan mahasiswa (55\%) menempatkan perpustakaan sebagai sarana yang paling banyak digunakan, dan sebagian besar dosen $(42 \%)$ dan mahasiswa (56\%) menempatkan laboratorium pada intensitas pemanfaatan terakhir atau keenam. Sementara itu, dalam hal pemanfaatan ruang diskusi, komputer, dan layanan jurnal, dosen menempatkan masing-masing aspek tersebut pada intensitas pertama (30\%), kelima (34\%), dan keempat $(25 \%)$. Hal ini berbeda dengan persepsi mahasiswa dimana terhadap semua aspek ini, mereka menempatkan yaitu masingmasing pada intensitas kelima (32\%), keempat (29\%), dan kedua (29\%). Dengan kata lain, pada aspek ruang diskusi, laboratorium, dan komputer yang disediakan oleh universitas belum banyak digunakan oleh para mahasiswa dalam menyelesaikan penulisan skripsinya, dan sebaliknya perpustakaan lebih banyak digunakan dalam proses penulisan skripsi.

\section{Hambatan-Hambatan}

Hambatan dalam penyusunan skripsi dapat berupa hambatan teknis penulisan, hambatan substansi materi, sarana pendukung, emosional, dan hambatan lainnya. Berikut ini disajikan informasi mengenai hambatan yang dipersepsikan oleh mahasiswa dan dosen dalam proses penyusunan skripsi.

Pertama, hambatan substansi materi. Ada sepuluh pilihan yang diajukan, yaitu: penentuan tema, penyusunan latar belakang, rumusan masalah, kajian teori, kerangka pikir, metode pnelitian, penyusunan instrumen, analisis data, pembahasan, dan pembuatan kesimpulan. Ada kesamaan pandangan antara dosen dan mahasiswa tentang hambatan pada aspek substansi. Secara umum, baik dosen (30\%) maupun mahasiswa $(34 \%)$ melihat penemuan tema penelitian dan penyusunan latar belakang masalah merupakan hambatan dengan intensitas pertama. Begitu pula penentuan rumusan masalah menjadi hambatan ketiga, kajian te- 
ori menjadi hambatan keempat, penyusunan kerangka pikir menjadi hambatan kelima, penentuan metode penelitian menjadi hambatan keenam, penentuan instrumen analisis data menjadi hambatan kedelapan, penulisan pembahasan menjadi hambatan dengan intensitas kesembilan dan intensitas terakhir adalah hambatan merumuskan kesimpulan. Nampaknya, hambatan-hambatan ini dapat terjadi seiring dengan urutan kegiatan proses pentahapan dalam penyusunan skripsi yang dilakukan mahasiswa. Dari informasi ini, hambatan yang dipandang penting/ memiliki intensitas kuat adalah penyusunan latar belakang dan perumusan masalah.

Kedua, hambatan teknis. Pilihan yang diajukan meliputi keterbatasan waktu, komunikasi dengan dosen, manajemen waktu, kedisiplinan, dan aktivitas dosen. Ada kesamaan pandangan antara dosen dan mahasiswa tentang hambatan yang sering dihadapi. Sebanyak 49\% dosen dan 24\% mahasiswa melihat kedisiplinan merupakan hambatan yang memiliki intensitas pertama. Sementara itu, manajemen waktu dilihat sebagai hambatan dengan intensitas kedua, baik oleh dosen (30\%) maupun mahasiswa (33\%). Padangan yang berbeda terjadi pada masalah aktivitas dosen dimana dosen memandang aktivitas dosen menjadi hambatan yang berada dalam intensitas kelima (43\%), sedangkan mahasiswa memandang aktivitas ini merupakan hambatan dalam intensitas pertama (31\%). Sementara itu, keterbatasan waktu dipandang oleh kedua pihak relatif tidak jauh berbeda dimana masing-masing menempatkan pada intensitas kelima dan keempat. Mendasarkan pada informasi ini, dapat diketahui bahwa hambatan teknis dalam penyusunan skripsi, yang paling pokok/ kuat adalah kedisiplinan dan manajemen waktu.

Ketiga, hambatan sarana pendukung. Ada enam aspek pilihan hambatan yang diungkap, yaitu: kelengkapan referensi dan prosiding, ruang konsultasi, kelengkapan sarana laboratorium, ketidaklancaran internet, pemilikkan komputer. Kedua belah memiliki kesamaan pandangan, baik dosen (43\%) maupun mahasiswa (61\%) menempatkan ketidaklengkapan referensi sebagai hambatan utama. Di samping itu, dosen (42\%) dan mahasiswa (47\%) merasakan kekuranglengkapan prosiding sebagai hambatan pada intensitas kedua. Sementara itu, hambatan lainnya, yaitu ruang konsultasi dan laboratorium, layanan internet, kepemilikkan komputer dipandang sebagai hambatan dengan intensitas empat, lima dan enam. Mendasarkan pada informasi ini dapat dinyatakan bahwa kedua kelompok responden memiliki persepsi yang sama terhadap hambatan pembimbingan skripsi. Ketidaklengkapan referensi dan prosiding merupakan hambatan yang sangat memberikan pengaruh penting pada penyelesaiaan penyusunan skripsi mahasiswa.

Keempat, teknik penulisan. Kesulitan memahami buku panduan skripsi, memadukan isi rujukan/teori, mengutip teori/pendapat, menulis alinea atau kalimat, menguasai bahasa asing, penggunaan bahasa baku ilmiah adalah faktor-faktor hambatan yang diungkap. Dengan memperhatikan frekuensi pendapat yang banyak muncul (modus), dapat dikemukakan bahwa ada kesamaan pandangan diantara kedua kelompok responden tentang intensitas kesulitan.. Secara berturut-turut, kesulitan memadukan pemikiran/teori sebagai hambatan dengan intensitas pertama, dosen $(32 \%)$ dan mahasiswa (35\%), kesulitan memahami buku panduan pada peringkat intensitas ke enam , dosen $(43 \%)$ dan mahasiswa (28\%), kesulitan penguasaan bahasa asing pada tingkat intensitas yang sama, yaitu keenam, dosen $(26 \%)$ dan mahasiswa (35\%). Sedangkan untuk kesulitan menulis alinea dipandang sebagai hambatan dengan intensitas empat oleh kedua kelompok dimaksud, dosen $(28 \%)$ dan mahasiswa (29\%). Hanya pada hambatan kurang memahami bahasa baku terdapat perbedaan dari keduanya, dimana dosen (34\%) menempatkan hambatan ini sebagai hal yang berada dengan intensitas pertama, sebaliknya mahasiswa $(26 \%)$ memposisikan hambatan ini dengan intensitas keenam.

Kelima, hambatan dalam pengumpulan data. Hambatan yang diungkap meliputi 
poses perijinan dari kampus, perijinan dari Pemda /lokasi penelitian, jangkauan lokasi penelitian, pengumpulan data. Terdapat kesamaan pandangan baik dosen dan mahasiswa, yaitu: $55 \%$ dosen dan $37 \%$ mahasiswa memandang pengumpulan data menjadi hambatan dengan intensitas pertama, dan alat tranportasi menjadi hambatan dalam intensitas kelima dengan modus masing-masing $45 \%$ dan $71 \%$. Di samping itu ada perbedaan pandangan antara dosen dan mahasiswa. Hambatan berupa perijinan dari kampus menurut dosen (42\%) berada dalam intensitas kelima, sedangkan menurut mahasiswa berbada dalam intensitas ketiga (24\%) keempat (24\%), dan kelima (25\%). Begitu pula terkait hambatan berupa jangkauan penelitian, menurut dosen (45\%) berada dalam intensitas kedua, sementara mahasiswa memandang sebagai hambatan dengan intensitas kedua, ketiga, keempat masing-masing dengan modus yang sama $(25 \%)$.

Keenam, hambatan dalam analisis data. Hambatan yang diungkap meliputi pemahaman konsep analisis data, prosedur analisis data, aplikasi/software analisis data dan interpretasi hasil analisis data. Dalam hal ini, antara dosen dan mahasiswa memiliki kesamaan pandangan, yaitu: tidak memahami konsep dianggap sebagai hambatan dengan intensitas pertama, dan penguasaan prosedur analisis data dipandang sebagai hambatan dengan intensitas kedua. Persentase modus masing-masing adalah 68\% dan 34\% untuk hambatan tidak memahami konsep, dan untuk hambatan tak memahmi prosedur memiliki persentase modus masingmasing 53\% dan 37\%. Begitu pula, terkait dengan hambatan kesulitan menggunakan program analisis data, dosen $(42 \%)$ dan mahasiswa (44\%) memposisikan pada intensitas keempat. Namun demikian, kedua pihak berbeda dalam memandang hambatan interpretasi hasil penelitian, dimana mahasiswa $(30 \%)$ memandang hambatan ini sebagai intensitas pertama sedangkan dosen (44\%) memposisikannya dengan intensitas keempat.

Ketujuh, hambatan emosional. Hal-hal yang diungkap meliputi kurang berani ber- pendapat, kurang percaya diri dalam berkonsultasi, kurang motivasi, kurang berani bertemu dosen, takut dimarahi/disalahkan dosen, takut dipersulit, dan kurang berani menolak pendapat dosen. Terdapat perbedaan persepsi antara dosen dan mahasiswa mengenai hambatan emosional mahasiswa dalam proses bimbingan. Mahasiswa memandang rasa kurang percaya diri dan kurang motivasi merupakan hambatan dengan intensitas pertama, masing-masing dengan modus $22 \%$ dan $24 \%$. Dalam hal kurang berani berpendapaat, mahasiswa menempakannya pada tingkat intensitas pertama, kedua, ketiga dan keempat secara merata atau tidak ada yang menonjol. Sementara itu, bagi dosen tidak ada hambatan emosinal yang berada pada tingkat intensitas pertama. Hambatan yang menonjol adalah kurang berani berpendapat (38\%) berada pada intensitas kedua, kurang percaya diri (34\%) berada pada tingkat intensitas ketiga. $\mathrm{Na}$ mun kedua kelompok responden memiliki kesamaan pandangan. Dosen dan mahasiswa menempatkan rasa takut dipersulit dengan modus masing-masing $32 \%$ dan $31 \%$, dan kurang berani menolak pendapat dengan modus masing-masing $49 \%$ dan $29 \%$ pada tingkat intensitas keenam dan ketujuh. Mendasarkan informasi ini, dapat disimpulkan bahwa dosen dan mahasiswa memiliki persepsi yang berbeda mengenai hambatan emosional dalam proses bimbingan skripsi; dosen memandang kurang percaya diri dan kurang termotivasi merupakan hambatan penting, dengan intensitas tiga; sementara itu mahasiswa melihat rasa kurang percaya diri, dan kurang termotivasi merupakan hambatan emosional dengan intensitas pertama.

\section{Upaya Mengatasi Hambatan}

Upaya mengatasi hambatan yang dihadapi dalam proses bimbingan dilihat dari dua sisi, yaitu: upaya yang dilakukan mahasiswa, dan dosen. Pertama, upaya mahasiswa. Hal yang diuangkap mencakup belajar sendiri, meningkatkan motivasi diri, meminta saran pada dosen lain, berdiskusi dengan teman, meminta saran pada dosen pembim- 
bing, mengatur irama belajar. Mahasiswa dan dosen memiliki perbedaan pendapat mengenai upaya yang dilakukan mahasiswa untuk mengatasi hambatan. Mahasiswa menempatkan upaya belajar sendiri sebagai intensitas pertama $(31 \%)$, upaya meningkatkan motivasi sebagai intensitas kedua $(29 \%)$, sedangkan dosen menempatkan kedua tindakan ini berada pada intensitas keempat dengan masing-masing $26 \%$ dan $32 \%$. Upaya meminta saran dosen lain diposisikan mahasiswa $(26 \%)$ dengan intensitas keenam, dan dosen (26\%) memposisikannya dengan intensitas ketiga. Begitu pula pada upaya diskusi dengan teman, dimana mahasiswa $(23 \%)$ memposisikan dalam intensitas kedua, sedangkan dosen (38\%) mempersepsikan dengan intensitas ketiga. Sama halnya dengan usaha meminta saran dosen pembimbing, mahasiswa $(26 \%)$ menempatkannya pada tingkat intensitas kelima, sementara dosen $(30 \%)$ memposisikannya pada tingkat intensitas kedua. Namun demikian ada satu kesamaan pandangan diantara dua kelompok responden dimana mahasiswa (44\%) dan dosen (62\%) menempatkan upaya mengatur irama belajar pada intensitas keenam.

Dari informasi di atas dapat disimpulkan bahwa persepsi dosen dan mahasiswa terhadap upaya yang dilakukan mahasiswa dalam mengatasi hambatan cenderung berbeda, dimana menurut mahasiswa upaya yang dipandang sebagai intensitas pertama adalah belajar sendiri dan meningkatkan motivasi diri; sedangkan dosen hanya memposisikan upaya mahasiswa dengan intensitas dua untuk upaya meminta saran dosen pembimbing.

Kedua, usaha dosen. Hal ini mencakup menyesuaikan tuntutan dengan kemampuan mahasiswa, menambah waktu bimbinngan, memberikan penjelasan lebih detail, meminta mahasiswa konsultasi pada dosen lain, menyerahkan sepenuhnya pada mahasiswa, memberi kesempatan mahasiswa menyampaikan permasalahaan yang dihadapi.

Terdapat sedikit perbedaan modus persepsi antara dosen dan mahasiswa mengenai upaya yang dilakukan dosen dalam mengatasi hambatan dalam proses pembimbingan skripsi. Dosen (36\%) menempatkan upaya memberikan penjelasan secara detail pada peringkat pertama, sementara mahasiswa (34\%) menempaktannya pada posisi kedua; Begitu pula usaha menambah waktu bimbingan, dosen $(30 \%)$ menempatkan pada intensitas keempat, dan mahasiswa (23\%) menempatkannya pada tingkat intensitas ketiga. Dosen $(40 \%)$ menempatkan upaya menyesuaikan tuntutan dengan kemampuan mahasiswa pada intensitas ketiga, sedangkan mahasiswa (26\%) memposisikanya pada tingkat intensitas keempat. Selain itu dosen (58\%) memandang upaya menyerahkan mahasiswa berkonsultasi dengan dosen lain pada posisi kelima, dan mahasiswa $(32 \%)$ menempatkannya pada posisi keenam. Namun, terdapat kesamaan persepsi antara keduanya mengenai upaya memberikan kesempatan pada mahasiswa untuk menyampaikan permasalahannya pada dosen dimana dosen (45\%) dan mahasiswa (24\%) memposisikannya pada intensitas pertama, dan menyerahkan pada mahasiswa untuk mengatasi masalahnya sendiri pada posisi intensitas keenam.

\section{Pembahasan}

Dari paparan hasil di atas dapat diketahui bahwa ada kecenderungan kesamaan dan perbedeaan modus persepsi mahasiswa dan dosen terhadap proses bimbingan skripsi. Banyak mahaiswa yang memiliki persepsi bahwa proses bimbingan dilakukan melalui diskusi, tatap muka, bersifat individual, dan pemberian kesempatan untuk menyampaikan permasalahan pada dosen. Hal ini berarti bahwa proses bimbingan tidak menggunakan pendekatan gaya bank, tetapi lebih mengedapankan dialog. Mahasiswa tidak diposisikan sebagai penerima pengetahuan atau informasi secara pasif. Proses ini akan menjadi lebih bermakna manakala hubungan dialogis tersebut tidak hanya digunakan untuk mengkaji pengetahuan tetapi untuk memaknai realitas atau dunia (Freire, 1980) sehingga mahasiswa tidak mengalami kesulitan di dalam menentukan tema dan mermuskan masalah peneli- 
tian. Kesulitan tersebut muncul, disebabkan di satu sisi mahasiswa tidak memiliki bekal pengetahuan, kemampuan berpikir dan menulis yang memadai (Mancha \& Yoder, 2014b). Di sisi lain, permasalahan penelitian tidak bersumber pada kebutuhan dan pengalaman mahasiswa (Knowles et al., 2005, p. 62).

Aspek lain yang cukup menarik adalah proses belajar mandiri yang dilakukan mahasiswa. Hal ini terlihat dari upaya mahasiswa di dalam mencari sumber referensi, menganalisis data, dan upaya dalam mengatasi hambatan, di mana ketiganya dilakukan secara mandiri. Hal ini dapat dipahami karena pada dasarnya mahasiswa sudah memasuki usia dewasa. Di usia ini individu sudah memiliki konsep diri. Oleh karena itu, individu sudah mampu mengarahkan dirinya sendiri. Hal ini sejalan dengan pemikiran Knowles et al. (2005, p. 187) yang menyatakan bahwa pada dasarnya orang dewasa sudah meimiliki konsep diri, dan oleh karena itu dapat mengarahkan proses belajarnya secara mandiri.

Proses perkembangan belajar mandiri berlangsung melalui empat tahap, yaitu: dependent Authority, yaitu bergantung sepenuhnya pada dosen, interested, tertarik pada perkuliahan dan diskusi terbimbing, involved, yaitu terlibat dalam disuksi dengan menempatkan diri secara sejajar dengan dosen, selfdirected, yaitu melakukan proses belajar mandiri secara penuh. Jika dilihat dari proses perkembangan ini maka pada umumnya mahasiswa berada pada tahap involved. Lebih lanjut dikemukakan bahwa dalam membantu mahasiswa menjalani proses belajar mandiri ini dapat dilakukan melalui empat tahapan, yaitu: mengembangkan kebutuhan belajar, mengembangkan strategi dan sumber belajar untuk mencapai tujuan, mengimplementasi strategi belajar dan memanfaatkan sumber belajar, dan mengevaluasi ketercapaian tujuan (Knowles et al., 2005, pp. 175-176). Senada dengan pendapat tersebut, Pamungkasari \& Probandari (2012, pp. 500-501) menyatakan bahwa untuk mengembangkan kemampuan belajar mandiri, di pertemuan awal perkuliahan dosen perlu membangun hubungan kesetaraan. Hal ini dimaksudkan untuk mengurangi ketergantungan mahasiswa pada dosen. Kemudian pada pertemuan selanjutnya dosen dan mahasiswa melakukan identifikasi kebutuhan belajar, tujuan, rencana pembelajaran dan evaluasi.

Sejalan dengan pemikiran tersebut, Kram (Schunk \& Mullen, 2013, p. 365) menemukan ada empat tahap dalam proses pembimbingan, yaitu: initiation adalah tahap dimana dosen dan mahasiswa saling menyesuaian diri; cultivation, dimana mahasiswa merasa memperoleh tambahan keterampilan, pengetahuan dari dosen, dan dosen merasa mendapat kepuasan atas loyalitas dan dukungan mahasiswa, dan dapat memberikan pengetahuan pada mahasiswa, separation, dimana dosen memberikan otonomi pada mahasiswa untuk melakukan proses belajar secara mandiri dan memperoleh nilai atau makna hubungan yang terjalin secara berkelanjutan; redefination; dimana proses pembimbingan ini akan berlanjut menjadi hubungan yang bersifat kekeluargaan dan bahkan hubungan yang bersifat profesional.

\section{Simpulan}

Berdasarkan paparan hasil penelitian dan pembahasan tentang proses pembimbingan skripsi mahasiswa Universitas Negeri Yogyakarta dapat ditarik kesimpulan sebagai berikut. Pertama, proses pembimbingan cenderung sudah menggunakan prinsip pembelajaran orang dewasa, dengan lebih menekankan pada proses dialog dan belajar mandiri (self ditrected learning). Hal ini ditunjukkan dengan proses bimbingan dilakukan melalui diskusi dan mahasiswa tidak menerima apa saja yang disampaikan dosen, tatap muka secara individual, pencarian sumber referensi dan analisis data secara mandiri, penanganan hambatan secara mandiri dan pemberian kesempatan dosen pada mahasiswa untuk menyampaikan masalah yang dihadapi.

Kedua, secara teknis kegiataan pembimbingan yang dilakukan adalah sebagai berikut: (1) sumber belajar yang intens digunakan adalah buku dan jurnal nasional;

Evaluasi Proses Bimbingan Skripsi Mahasiswa ... - 
(2) proses belajar dilakukan secara mandiri oleh mahasiswa dan dibimbing oleh dosen; (3) fasiltas yang paling banyak digunakan adalah perpustakaan. Sementara itu, ruang diskusi, layanan jurnal, dan komputer yang disediakan oleh universitas belum banyak digunakan oleh para mahasiswa.

Hambatan yang paling intens dihadapi dalam proses bimbingan meliputi: (1) hambatan substansi, yaitu: dan penyusunan latar belakang masalah dan perumusan masalah, (2) hambatan teknis penulisan, yaitu: memadukan pemikiran/teori, (3) hambatan teknis, yaitu: ketidakdisiplinan dan manajemen waktu yang dilakukan oleh para mahasiswa, (4) hambatan sarana berupa ketidaklengkapan referensi dan prosiding, (5) hambatan teknis pengumpulan data dan interpretasi hasil data, (6) terdapat perbedaan persepsi antara dosen dan mahasiswa mengenai intesitas hambatan emosional dalam proses bimbingan skripsi. Dosen memandang kurang percaya diri dan kurang termotivasi merupakan hambatan pada intensitas ketiga, sedangkan mahasiswa melihat bahwa kurang percaya diri, dan kurang termotivasi merupakan hambatan emosional dengan intensitas pertama.

Upaya yang dilakukan dalam mengatasi hambatan, yaitu: (1) Dosen memberikan kesempatan pada mahasiswa untuk menyampaikan permasalahan yang dihadapi, (2) terdapat perbedaan persepsi antara mahasiswa dan dosen terhadap intensitas upaya yang dilakukan dalam mengatasi hambatan. Menurut mahasiswa upaya yang dipandang memiliki intensitas pertama adalah belajar mandiri dan meningkatkan motivasi diri; sedangkan dosen adalah meminta saran dosen pembimbing.

Berdasarkan kesimpulan tersebut maka untuk meningkatkan proses pembimbingan skripsi diajukan saran sebagai berikut. Pertama, proses pembimbingan tidak hanya memperhatikan masalah substansi, tetapi juga perlu memperhatikan aspek psikologis mahasiswa, seperti kepercayaan diri, manajemen waktu, motivasi. Oleh karena perlu dikembangkan hubungan yang lebih bersifat personal dan informal. Kedua, perlu meningkatkan penguasaan masalah penelitian, metode penelitian dan kemampuan bahasa asing mahasiswa. Ketiga, perlu menambah ketersediaan sumber referensi seperti buku, prosiding.

\section{Daftar Pustaka}

Brew, A. (2013). Understanding the scope of undergraduate research: a framework for curricular and pedagogical decision-making. Higher Education, 66(5), 603-618. https://doi.org/10.1007/s10734-0139624-x

Deloach, S. B., Perry-Sizemore, E., \& Borg, M. O. (2012). Creating quality undergraduate research programs in economics: how, when, where (and why). The American Economist, 57(1), 96-110. https://doi.org/10.1177/05694345120 5700108

Dobozy, E. (2011). Constrained by ideology: attitudinal barriers to undergraduate research in Australian teacher education. E-Journal of Business Education \& Scholarship of Teaching, 5(2), 36-47.

Flynn, T. (Terry). (2014). Do they have what it takes: A review of the literature on knowledge, competencies and skills necessary for 21 st century public relations practitioners in Canada. Canadian Journal of Communication, 39(3).

Freire, P. (1980). Pendidikan kaum tertindas (Terjemahan). Jakarta: LP3ES.

Harsh, J. A., Maltese, A. V, \& Tai, R. H. (2011). Undergraduate research experiences from a longitudinal perspective. Journal of College Science Teaching, 41(1), 84-91. Retrieved from http://www.jstor.org/stable/4374828 7

Hunter, A.-B., Laursen, S. L., \& Seymour, E. (2007). Becoming a scientist: The role of undergraduate research in students' cognitive, personal, and 
professional development. Science

Education, 91(1), 36-74.

https://doi.org/10.1002/sce.20173

Husin, W. N. F. W., Arsad, N. M., Othman, O., Halim, L., Rasul, M. S., Osman, K., \& Iksan, Z. (2016). Fostering students' 21 st century skills through project oriented problem based learning (POPBL) in integrated STEM education program. Asia-Pacific Forum on Science Learning and Teaching, 17(1).

Ishiyama, J. (2002). Does early participation in undergraduate research benefit social science and humanities students? College Student Journal, 36(3), 381-387.

Jenkins, A., \& Healey, M. (2010).

Undergraduate research and international initiatives to link teaching and research. Council on Undergraduate Research, 30(3), 36-42.

Knowles, M. S., Holton III, E. F., \& Swanson, R. A. (2005). The adult learner: the definitive classic in adult education and buman resource development. The Adult Learner (6th ed.). New York: Elsevier.

Kovacevic, M., \& Pavlovic, N. (2016). Globalization and the knowledge society. Ekonomika, 62(4), 95-104. https://doi.org/10.5937/ekonomika1 604095K

Magolda, M. B. B. (2007). Self-authorship: The foundation for twenty-firstcentury education. New Directions for Teaching and Learning, 2007(109), 69-83. https://doi.org/10.1002/tl.266

Mancha, R., \& Yoder, C. Y. (2014a). Factors critical to successful undergraduate research. Council on Undergraduate Research Quarterly. Retrieved from https://www.thefreelibrary.com/Fact ors + critical+to+successful+undergrad uate + research.-a0377777162

Mancha, R., \& Yoder, C. Y. (2014b). Factors critical to successful undergraduate research. Council on Undergraduate Research Quarterly.

Menteri Pendidikan dan Kebudayaan Republik Indonesia. Peraturan Menteri Pendidikan dan Kebudayaan Republik Indonesia Nomor 49 Tahun 2014 tentang Standar Nasional Pendidikan Tinggi (2014).

Odera, E., Lamm, A. J., Odera, L. C., Duryea, M., \& Davis, J. (2015). Understanding how research experiences foster undergraduate research skill development and influence STEM career choice. North American Colleges and Teacher of Agriculture, 59(3).

Pamungkasari, E. P., \& Probandari, A. (2012). Pengukuran kemampuan belajar mandiri pada mahasiswa pendidikan profesi dokter. Jurnal Penelitian Dan Evaluasi Pendidikan, 16(2). Retrieved from https://journal.uny.ac.id/index.php/jp ep/article/view/1128

Schunk, D. H., \& Mullen, C. A. (2013). Toward a conceptual model of mentoring research: integration with self-regulated learning. Educational Psychology Review, 25(3), 361-389. https://doi.org/10.1007/s10648-0139233-3

Webber, K. L., Laird, T. F. N., \& BrckaLorenz, A. M. (2013). Student and faculty member engagement in undergraduate research. Research in Higher Education, 54(2), 227-249. Retrieved from http://www.jstor.org/stable/2335528 7

Yamada, A., \& Yamada, R. (2016). Impact of globalization on Japanese Higher Education Policy: examining campus internationalization and challenge of Japanese Universities. Current Politics and Economics of Northern and Western Asia, 25(1). 